\title{
Dampak Islamic Corporate Governance , Islamic Social Reporting Pada Kinerja Keuangan Bank Syariah di Indonesia
}

\author{
Sutapa ${ }^{1}$ \\ Rustam Hanafi ${ }^{2}$ \\ 1,2 Mahasiswa Universitas Diponegoro Semarang
}

\begin{abstract}
ABSTRAK
Penelitian ini menekankan pada pengaruh Ukuran Dewan Pengawas Syariah dan keahlian Dewan Pengawas Syariah terhadap pengungkapan Islamic Social Reporting serta implikasinya terhadap kinerja keuangan. Penelitian ini bertujuan untuk memperoleh bukti empiris tentang pengaruh Ukuran Dewan Pengawas Syariah dan keahlian Dewan Pengawas Syariah terhadap pengungkapan Islamic Social Reporting (ISR) serta pengaruhnya terhadap kinerja keuangan pada perbankan syariah di Indonesia. Populasi dalam penelitian ini adalah seluruh bank umum syariah di Indonesia yang terdaftar pada Bank Indonesia. Periode pengamatan dalam penelitian ini adalah tahun 2013-2017. Metode penentuan sampel dalam penelitian ini adalah purposive sampling. Ada tujuh bank dan diperoleh 35 observasi. Uji asumsi klasik dilakukan untuk analisis data dan analisis regresi untuk menguji hipotesis. Hasil penelitian ini menunjukkan bahwa ukuran dewan pengawas syariah berpengaruh positif dan signifikan terhadap tingkat pengungkapan Islamic Social Reporting, namun keahlian dewan pengawas syariah tidak memiliki pengaruh signifikan, sedangkan Islamic Social Reporting berpengaruh terhadap kinerja keuangan perbankan syariah.
\end{abstract}

Kata Kunci: ukuran dewan pengawas syariah, keahlian dewan pengawas syariah, Islamic Social Reporting, Kinerja Keuangan

\section{PENDAHULUAN}

Keberadaan perbankan syariah di Indonesia merupakan refleksi dari kebutuhan atas sistem perbankan alternatif yang lebih dapat memberikan kontribusi positif untuk meningkatkan stabilitas sistem perbankan nasional. Hal ini membuat pemerintah Indonesia untuk menetapkan peraturan-peraturan dan standar akuntansi bagi bank syariah. Selain itu pesatnya perkembangan bank syariah juga mendorong bank syariah untuk dapat melaporkan pengungkapan tanggung jawab sosialnya yang sesuai dengan prinsip-prinsip syariah Islam untuk menilai kinerja keuanganya. Dengan mengungkapkan tanggungjawab social akan memberikan dampak terhadap kinerja perbankan.

Pada saat ini konsep dari CSR tidak hanya digunakan dalam dunia ekonomi konvensional, namun juga sudah berkembang pada ekonomi Islam. Di Indonesia semakin banyak perusahaan berasaskan syariah yang berkembang, hal ini menandakan bahwa ekonomi Islam juga sedang mengalami peningkatan. Akibat dari perkembangan ini, dalam ekonomi Islam juga turut meningkatkan perhatian masyarakat terhadap lembaga atau institusi syariah. Dalam rangka untuk memenuhi pelaporan perusahaan mengenai tanggung jawab sosial 
yang berbasis syariah, maka umat muslim mulai mengembangkan peraturan yang disesuaikan dengan nilainilai Islam dan dikenal sebagai Islamic Social Reporting (ISR). ISR pertama kali dikenalkan oleh Haniffa pada tahun 2002 dengan melakukan pengungkapan 5 tema. Konsep ini dikembangkan oleh Othman dkk. pada tahun 2009 yang menambahkan satu tema dalam pengungkapan ISR yaitu tata kelola perusahaan.

Selain itu Islamic Social Reporting juga menjadi suatu hal yang penting bagi reputasi dan kinerja lembaga keuangan syariah, karena dengan mengungkapan ISR, lembaga keuangan syariah yang dapat mengungkapkan ISRnya dengan sangat baik akan dipandang sebagai lembaga yang dapat dipercaya oleh masyarakat muslim dalam menyalurkan dana mereka. Kinerja keuangan dari bank merupakan gambaran sebenarnya dari kondisi keuangan bank pada suatu periode tertentu baik mencakup aspek penyaluran dana ataupun penghimpunan dananya. Loyalitas serta kepercayaan pemilik dana terhadap bank merupakan faktor yang sangat membantu dan mempermudah pihak manajemen bank dalam menyusun strategi bisnis yang baik. Pemilik dana sewaktuwaktu dapat menarik dananya dan memindahkan ke bank lain apabila para pemilik dana kurang memnaruh kepercayaan terhadap bank yang bersangkutan maka loyalitasnyapun sangat tipis. Penilaian terhadap kinerja suatu bank dapat dilakukan dengan menganalisis laporan keuangannya. Laporan keuangan bank berupa neraca memberikan informasi kepada pihak eksternal, misalnya masyarakat, investor dan bank sentral, mengenai gambaran posisi keuangannya. Laporan neraca ini dapat digunakan pihak eksternal untuk menilai besarnya resiko yang ada pada suatu bank. Kemudian laporan laba rugi memberikan gambaran tentang perkembangan bank yang bersangkutan.

Terkait dengan pengungkapan tanggung jawab sosial suatu entitas syariah, akhir-akhir ini marak diperbincangkan mengenai Islamic Social Reporting. Islamic Social Reporting adalah standar pelaporan kinerja sosial perusahaan berbasis syariah. Islamic Social Reporting merupakan kerangka khusus untuk pelaporan pertanggungjawaban sosial yang sesuai dengan prinsip Islam. Tujuan dari Islamic Social Reporting sendiri adalah sebagai bentuk akuntabilitas perusahaan kepada Allah SWT dan masyarakat dan juga meningkatkan transparansi kegiatan bisnis dengan menyajikan informasi yang relevan dengan memperhatikan kebutuhan spiritual investor muslim atau kepatuhan syariah dalam pengambilan keputusan.

Islamic Social Reporting terdiri atas item-item standar CSR yang ditetapkan AAOIFI (Accounting and Auditing Organization for Islamic Institutions) dan kemudian dikembangkan lagi oleh para peneliti mengenai itemitem CSR yang patut diungkapkan oleh suatu entitas Islam. Indeks ISR tersebut berisi 6 (enam) tema antara lain: investasi dan keuangan, produk dan jasa, karyawan, masyarakat, lingkungan, serta tata kelola perusahaan. Masing-masing tema memiliki indikator-indikator, yang seluruhnya berjumlah 43 indikator. Ada beberapa faktor yang dapat mempengaruhi terhadap pengungkapan ISR antara laian kepemilikan institusioanl dan ukuran perusahaan.

Studi mengenai pengungkapan tanggung jawab sosial yang dilakukan Haniffa (2002) menjelaskan bahwa ada keterbatasan pada kerangka pelaporan sosial yang dilakukan oleh lembaga konvensional. Keterbatasan tersebut mencakup aspek-aspek spiritual dan moral, sebab dalam prinsip syariah tidak hanya berfokus kepada aspek material saja seperti zakat, status kepatuhan syariah dan transaksi yang sudah terbebas dari unsur riba, serta aspek social seperti sodaqoh, waqof, qordul hasan, sampai dengan pengungkapan peribadahan 
di lingkungan perusahaan. Karenanya diperlukan sebuah kerangka pelaporan sosial yang berdasarkan prinsip syariah dalam mengembangkan Islamic Social Reporting untuk mencapai tujuan akuntabilitsas dan transparansi.

Beberapa penelitian yang telah dilakukan mengenai Islamic Social Reporting (ISR), antara lain Astuti (2014) yang meneliti tentang faktor-faktor yang mempengaruhi pengungkapan Islamic Social Reporting pada Bank Syariah di Indonesia. Hasil penelitian menunjukkan bahwa ukuran perusahaan berpengaruh terhadap pengungkapan Islamic Social Reporting. Penelitian yang dilakukan oleh Ratna Aditya Ningrum et.al (2013), menunjukkan bahwa kepemilikan institusional berpengaruh terhadap pengungkapan Islamic Social Reporting (ISR), sedangkan tipe industri bukanlah faktor penting yang mempengaruhi Islamic Social Reporting (ISR) secara signifikan.

Penelitian terdahulu mengenai Dewan Pengawas Syariah (DPS) juga dianggap berpengaruh terhadap pengungkapan ISR, hasilnya menunjukkan bahwa ukuran dewan pengawas syariah maupun keahlian dewan pengawas syariah semakin baik, maka semakin baik pula pengawasan terhadap pengungkapan Islamic Social Reporting yang dilaksanakan. Pendapat ini didukung oleh Widiastuti dan Firman (2016) yang menyebutkan bahwa keberadaan DPS dapat memberikan pengaruh terhadap tanggung jawab sosial perusahaan. Dewan Pengawas Syariah (DPS) dapat mewakili stakeholder yang lebih luas terkait dengan sharia assurance atas seluruh kegiatan operasional bank syariah.

Pada tahun 2015 berdasarkan hasil penelitian sebelumnya yang dilakukan oleh Haribowo, menentukan bahwa keberadaan Dewan Pengawas Syariah dan Keahlian Dewan Pengawas Syariah tidak berpengaruh pada tingkat pengungkapan ISR. Begitu pula dengan hasil penelitian yang dilakukan oleh Rahayu dan Cahyati (2014) yang Aldehita Purnasanti Maulida et.al (2014), melakukan penelitian pada perusahaan yang terdaftar pada Jakarta Islamic Index (JII), Faktor ukuran perusahaan tidak berpengaruh terhadap pengungkapan Islamic Social Reporting (ISR). Irman Firmansyah dan Eko Hariyanto (2014), hasil penelitian menunjukkan bahwa ukuran perusahaan dan dewan komisaris berpengaruh positif terhadap pengungkapan sosial perbankan syariah, sementara kepemilikan institusional tidak berpengaruh terhadap pengungkapan sosial perbankan syariah di Indonesia. Hasil penelitian Rita Rosiana et.al. (2015) menunjukkan bahwa ukuran perusahaan memiliki pengaruh signifikan terhadap pengungkapan pelaporan sosial Islam.

Penelitian dari Abi Rafdi Arsyi tahun 2015 menyatakan bahwa Islamic Social Reporting tidak berpengaruh signifikan terhadap kinerja keuangan. Berbanding terbalik dengan penelitian yang dilakukan oleh Harahap et all. (2017) menunjukkan bahwa ISR berpengaruh signifikan terhadap kinerja keuangan.

Berdasarkan penelitian-penelitian tersebut terdapat beberapa hasil yang tidak konsisten sehingga perlu dilakukan pengujian lebih lanjut untuk mengetahui konsistensi temuan jika diterapkan pada kondisi lingkungan yang berbeda.

Adapun rumusan masalah dalam penelitian ini adalah: Apakah ukuran dan keahlian dewan pengawas syariah berpengaruh terhadap /slamic Social Reporting dan bagaimana pengaruhnya terhadap Kinerja Keuangan. Penelitian ini memiliki tujuan yaitu untuk menguji pengaruh ukuran dan keahlian dewan pengawas syariah berpengaruh terhadap Islamic Social Reporting dan pengaruhnya terhadap Kinerja Keuangan. 


\section{KAJIAN PUSTAKA DAN PENGEMBANGAN HIPOTESIS}

Legitimasi organisasi dapat dilihat sebagai sesuatu yang diberikan masyarakat kepada perusahaan dan sesuatu yang diinginkan atau dicari perusahaan dari masyarakat (Chariri dan Ghozali, 2007). Teori legitimasi memfokuskan untuk menganjurkan perusahaan agar meyakinkan bahwa aktivitas dan kinerja yang dilakukan perusahaan dapat diterima oleh masyarakat.

Teori stakeholder adalah teori yang umumnya berkaitan dengan cara-cara yang digunakan perusahaan untuk mengelola stakeholdernya (Gray et al. 1997 dalam Chariri dan Ghozali, 2007). Salah satu strategi yang digunakan perusahaan untuk menjaga hubungan dengan para stakeholder-nya adalah dengan melakukan pengungkapakan informasi sosial dan lingkungan.

Indeks ISR berisi kompilasi item-item standar CSR yang ditetapkan oleh AAOIFI (Accounting and Auditing Organization for Islamic Financial Institutions) yang kemudian dikembangkan oleh para peneliti mengenai item-item CSR yang seharusnya di ungkapkan oleh suatu entitas Islam (Haryanti,2012). Ada enam tema pengungkapan dalam indeks ISR yaitu, investasi dan keuangan, produk dan jasa, tenaga kerja, sosial, lingkungan dan tata kelola perusahaan.

Terdapat banyak faktor yang mempengaruhi tingkat pengungkapan ISR. Pada penelitian ini dipilih profitabilitas, ukuran perusahaan, kinerja lingkungan dan leverage yang diprediksi dapat mempengaruhi pengungkaan ISR terkait sejauh mana informasi dari item-item ISR diungkapkan dalam laporan tahunan perusahaan.

\section{Pengaruh Ukuran Dewan Pengawas Syariah terhadap Islamic Social Reporting.}

Menurut Chariri (2012) kewajiban atas keberadaan Dewan Pengawas Syariah (DPS) pada institusi keuangan Islam telah diatur oleh Accounting and Auditing Organization for Islamic Financial Institutions (AAOFI) dalam Governance Standard for Islamic Financial Institutions (GSIFI). Dewan Pengawas Syariah memiliki peranan penting bagi perkembangan perbankan syariah.

Fungsi utama dewan pengawas syariah yaitu mengarahkan, meninjau dan mengawasi kegiatan bank syariah serta harus memastikan bahwa bank syariah telah berjalan sesuai dengan hukum islam. Wewenang yang dimiliki dewan pegawas syariah tersebut diyakini dapat meningkatkan pengungkapan tanggung jawab sosial perbankan syariah (Taufiq, dkk., 2015).

Dalam penelitian ini, Keberadaan Dewan Pengawas Syariah (DPS) akan menjadi variabel independen pengukuran Islamic Corporate Governance. Penelitian sebelumnya yang dilakukan oleh Othman, dkk. (2009), Ari Purwanti (2016), begitu pula dengan penelitian Febri Ramadhani (2016) yang mengungkapkan bahwa Keberadaan Dewan Pengawas Syariah mempunyai pengaruh positif signifikan terhadap pengungkapan Islamic Social Reporting. Berdasarkan analisis teoritis dan penelitian terdahulu hipotesis dirumuskan sebagai berikut:

$\mathbf{H}_{\mathbf{1}}$ : Ukuran Dewan Pengawas Syariah berpengaruh positif signifikan terhadap Islamic Social Reporting. 


\section{Pengaruh Keahlian Dewan Pengawas Syariah terhadap Islamic Social Reporting.}

Tugas pokok dan concern utama dari Dewan Pengawas Syariah adalah dalam hal sharia complimant, Chariri (2012). Keahlian yang harus dimiliki Dewan Pengawas Syariah adalah dalam bidang keuangan/perbankan, selain itu kompetensi sangat dibutuhkan bagi DPS terutama keahlian dalam hal hukum Islam. Paragraf kedua dalam GSIFI no.1 tentang Dewan Pengawas Syariah : Penunjukka, komposisi dan Laporan, memberikan rekomendasi tentang keahlian DPS. Perbankan syariah harus menunjukkan dan mengangkat DPS dengan keahlian utama fiqh muamalah, namun hendaknya diangkatpula seorang yang ahli dalam bidang institusi keuangan Islam (ahli keuangan dan perbankan) dengan pengetahuan fiqh muamalah. (Chariri, 2010)

Hasil penelitian terdahulu yang dilakukan oleh Chariri (2012) dan Firman, dkk. (2016) mengungkapkan bahwa keahlian DPS berpengaruh signifikan positif terhadap tingkat pengungkapan CSR pada Bank Syariah. Atas dasar analisis teoritis dan hasil penelitian terdahulu hipotesis dirumuskan sebagai berikut:

$\mathbf{H}_{\mathbf{2}}$ : Keahlian Dewan Pengawas Syariah berengaruh positif signifikan terhadap Islamic Social Reporting.

\section{Pengaruh Islamic Social Reporting terhadap Kinerja Keuangan (ROA)}

Pengungkapan tanggung jawab sosial (ISR) merupakan variabel yang menunjukkan seberapa besar pertanggungjawaban sosial perusahaan kepada publik. Setiap kegiatan perusahaan dalam ISR mampu membantu perusahaan dalam menjaga citranya kepada publik. Sehingga kedepannya akan menarik perhatian investor untuk menanamkan modalnya pada perusahaan. Oleh karena itu, semakin banyak perusahaan mengungkapkan pertanggungjawaban sosialnya diharapkan akan mempengaruhi profitabilitasnya (ROA) (Harahap dkk., 2017).

Hasil penelitian terdahulu yang dilakukan oleh Adisaputra, dkk. (2016) dan Harahap, dkk. (2017) menyatakan bahwa Islamic Social Reporting berpengaruh signifikan terhadap ROA. Hipotesis yang dirumuskan berdasarkan hasil uraian di atas yaitu:

$\mathbf{H}_{3}$ : Islamic Social Reporting berpengaruh positif signifikan terhadap Kinerja Keuangan (ROA).

\section{METODE PENELITIAN}

Populasi yang digunakan dalam penelitian ini adalah seluruh bank umum syariah yang ada di Indonesia. Adapun teknik pengambilan sampel menggunakan metode purposive sampling, yaitu bank umum syariah yang menerbitkan laporan tahunan 2015-2017. Jenis data yang digunakan merupakan data sekunder yang berasal dari laporan keuangan tahunan, dimana data tersebut dapat diperoleh pada situs masing-masing bank umum syariah.

Teknik pengumpulan data dalam penelitian ini dilakukan dengan metode studi dokumentasi yaitu pengumpulan data melalui dokumen, dalam hal ini data laporan tahunan diperoleh melalui situs masingmasing bank umum syariah dan studi pustaka yaitu pengumpulan data sebagai landasan teori serta penelitian terdahulu melalui buku- buku, penelitian terdahulu, serta sumber tertulis lainnya yang berhubungan dengan informasi yang dibutuhkan. Metode analisis data dalam penelitian ini meliputi statistik deskriptif, uji normalitas data, uji multikolinearitas, uji autokorelasi dan uji heterokedastisitas. Dan pengujian hipotesis menggunakan analisis regresi linier berganda. 


\section{Teknik Analisis Data}

Teknik analisis data yang digunakan dalam penelitian ini adalah analisis statistik deskriptif dan regresi liniear berganda. Kemudian dilakukan uji asumsi klasik dan uji kelayakan model. Model regresi dalam penelitian ini sebagai berikut:

$$
\begin{aligned}
& \mathrm{ISR}=a+\beta_{1} \text { UDPS }+\beta_{2} \mathrm{KDPS}+\varepsilon . \\
& \mathrm{KK}=a+\beta_{1} \mathrm{ISR}+\varepsilon
\end{aligned}
$$

\section{Dimana:}

$$
\begin{array}{ll}
\text { ISR } & =\text { Islamic Social Reporting } \\
\text { UDPS } & =\text { Ukuran Dewan Pengawas Syariah } \\
\text { KDPS } & =\text { Keahlian Dewan Pengawas Syariah } \\
\mathrm{KK} & =\text { Kinerja Keuangan } \\
\beta_{1} \beta_{2} & =\text { Koefisien Regresi } \\
\varepsilon & =\text { Koefisien Eror } \\
a & =\text { Konstanta }
\end{array}
$$

\section{HASIL DAN PEMBAHASAN}

Ada beberapa uji untuk mengetahui apakah variabel yang diuji memiliki distribusi normal atau tidak, untuk mengetahui ada atau tidaknya hubungan linear antar variabel independen dalam model regresi dan menguji apakah dalam model regresi terjadi ketidaksamaan variance dari residual satu pengamatan ke pengamatan yang lain. Berikut adalah ringkasan hasil ketiga asumsi dalam penelitian ini.

Berdasarkan hasil olah statistik diperoleh hasil bahwa variabel memiliki distribusi normal, tidak terjadi multikoleniaritas/ tidak ada hubungan linier antar variabel independen (nilai VIF dibawah 10) dan dalam model regresi tidak terjadi heterokedastisitas (nilai signifikan diatas 0,05 ).

\section{Analisis Regresi Linier Berganda}

Berdasarkan hasil perhitungan dengan menggunakan SPSS diperoleh hasil pada tabel 2

\section{PEMBAHASAN}

Pengaruh Ukuran Dewan Pengawas Syariah Terhadap ISR

Berdasarkan hasil penelitan menunjukkan bahwa nilai t sebesar 0,002 dengan signifikansi sebesar 0,004 sehingga hipotesis yang menyatakan bahwa ukuran Dewan Pengawas Syariah (DPS) berpengaruh positif signifikan terhadap Islamic Social Reporting (ISR) diterima. Ukuran dewan pengawas Syariah yang diukur menggunakan jumlah dewan pengawas Syariah akan memberikan pengawasan terhadap seluruh kegiatan operasional perbankan Syariah agar terjamin kesesuaiannya terhadap prinsip-prinsip syariah. Kegiatan tersebut antara lain menyalurkan zakat, infaq dan sodaqoh yang bisa diakui sebagai bentuk ISR. Jumlah dewan pengawas Syariah yang ada di tiap perbankan Syariah antara 2 sampai 5 orang (peraturan BI No. 6/24/PBI/2004). Dengan adanya jumlah dewan pengawas Syariah yang rata-rata 2 orang akan mendukung legitimasi teori 
yang mendorong organisasi supaya berperilaku dengan memperhatikan nilai sosial di lingkungan organisasi.

Hasil penelitian ini sesuai dengan hasil penelitian yang dilakukan oleh Purwanti (2016) dan Ramadhani (2016) yang menyatakan bahwa ukuran dewan pengawas syariah berpengaruh terhadap pengungkapan ISR. Jadi tidak dapat dipungkiri bahwa anggota dewan pengawas syriah yang cukup banyak dengan beragam pengalaman, prespektif dan kompetensi dalam hal hukum Islam akan membuat kinerja bank semakin efektif terutama pada hal pengungkapan ISR.

\section{Pengaruh Keahlian Dewan Pengawas Syariah Terhadap ISR}

Hipotesis 2 menyatakan bahwa keahlian dewan pengawas syariah berpengaruh positif terhadap ISR. Namun berdasarkan hasil penilaian dari uji t yang menunjukkan bahwa nilai t 1,279 dengan tingkat signifikansi sebesar 0,074 yang lebih besar dari 0,05 sehingga hipotesis ditolak. Sesuai dengan peraturan Bank Indonesia No. 6/24/PBI/2004 yang menyatakan bahwa setiap anggota Dewan Pengawas Syariah (DPS) harus memenuhi persyaratan kompetensi antara lain adalah pihak-pihak yang memiliki pengetahuan dan pengalaman dibidang syariah mu'amalah dan pengetahuan dibidang perbankan dan atau keuangan secara umum. Namun pada kenyataannya pada bank umum syariah yang menjadi sampel dalam penelitian ini masih belum memenuhi kriteria tersebut.

Pengalaman dan pengetahuan yang dimiliki oleh DPS masih sebatas pada ahli ekonomi saja. Masih ada beberapa DPS yang terdapat di Bank Umum Syariah yang belum memiliki pengetahuan atau pengalaman di bidang perbankan, hal ini terlihat dari profil masing-masing susunan dewan pengawas syariah setiap bank umum syariah. Jika peran DPS tidak berjalan optimal, maka akan ada kemungkinan syariah compliance yang dilanggar dan mengakibatkan kredibilitas dan kepercayaan nasabah akan menurun terhadap bank syariah. Hasil penelitian ini juga tidak sejalan teori legitimasi dimana keahlian dewan pengawas syariah yang seharusnya bisa meningkatkan reputasi perbankan, menjaga image dan strategi perbankan namun pada keyataannya keahlian yang dimiliki oleh DPS belum memenuhi kriteria yang ditetapkan.

Hasil penelitian ini berbeda dengan Chariri (2012) yang menyatakan keahlian DPS berpengaruh positif terhadap pengungkapan CSR pada bank umum syariah di Indonesia dan penelitian dari Firman dan Widiastuti (2016) yang mengungkapkan bahwa keahlian DPS berpengaruh positif terhadap Islamic Social Reporting Disclosure. Perbedaan hasil penelitian ini disebabkan karena sampel data yang diambil dan indeks ISR yang digunakan.

\section{Pengaruh Islamic Social Reporting Terhadap Kinerja Keuangan}

Hipotesis 3 menyatakan bahwa Islamic Social Reporting (ISR) berpengaruh positif signifikan terhadap kinerja keuangan yang diukur menggunakan Return On Assets (ROA). Berdasarkan hasil penelitian dapat dilihat bahwa nilai t sebesar 1,126 dengan tingkat signifikansi dari variabel ISR sebesar 0,039 yang lebih kecil dari 0,05. Sehingga hipotesis 3 diterima. Peningkatan pengungkapan tanggung jawab sosial perusahaan akan berdampak pada meningkatnya kinerja keuangan. Faktor pengungkapan tanggung jawab sosial merupakan tugas dari perbankan untuk menciptakan keberlanjutan ekonomi. 
Masyarakat akan melihat dan mepertimbangkan dalam memilih dan melakukan lalu lintas keuangan pada bank tertentu, mengingat fungsi dari bank adalah sebagai sebagai lembaga intermediasi yang menuntut bank mendapatkan legitimasi dari masyarakat. Kemampuan suatu bank dalam menghasilkan laba turut dipengaruhi oleh aktivitas sosial yang dilakukan oleh bank umum syariah, karena pelaksanaan tanggung jawab sosial perbankan akan membentuk image bank itu sendiri. ISR menggambarkan fungsi sosial bank syariah baik dari persefektif hukum positif maupun agama Islam. Hasil penelitian ini menunjukkan bahwa bank syariah yang dapat menjalankan fungsi sosialnya dengan baik dan disertai dengan pengungkapannya pada laporan tahunan dapat memberikan dampak positif terhadap kinerja keuangan. Semakin baik bank syariah dalam menginformasikan kegiatan sosialnya maka aspek keuangan akan meningkat pula. Pilantrofi Islam berupa Zakat, Infak, Sedekah dan Waqaf menjadi program utama CSR bank syariah. Bank syariah dapat berperan sebagai lembaga intermediasi sosial untuk program tersebut. Melalui jaringan infrastruktur yang baik yang dimiliki oleh bank syariah maka program sosial akan lebih baik. Funghsi Sosial dan fungsi komersial yang melekat pada bank syariah dapat diintegrasikan sehingga menjadi saling menguntungkan. Kinerja sosial dapat meningkatkan kinerja keuangan atau sebaliknya.

Hasil penelitian ini sejalan dengan hasil penelitian yang dilakukan oleh Harahap, dkk. (2017) dan Adisaputra, dkk. (2016) yang menyatakan bahwa ISR berpengaruh positif terhadap kinerja keuangan (ROA). Jadi peningkatan pengukapan Islamic Social Reporting juga akan meningkatkan kinerja keuangan pada Bank Umum Syariah di Indonesia. Terlihat juga dari faktor kepercayaan yang dimikili oleh maysarakat terhadap sebuah Bank Umum Syariah melalui pengungkapan kegiatan sosial masyarakat dan lingkungan

\section{SIMPULAN DAN SARAN}

\section{Simpulan}

Adapun simpulan dalam penelitian ini adalah :

1. Ukuran Dewan Pengawas Syariah berpengaruh terhadap pengungkapan ISR

2. Keahlian Dewan Pengawas Syariah tidak berpengaruh terhadap pengungkapan ISR Pengungkapan ISR berpengaruh terhadap kinerja keuangan perbankan syari'ah.

\section{Saran}

Adapun saran yang dapat diberikan adalah:

1. Bagi bank syariah dapat mengungkapkan Islamic Social reporting secara lebih luas dan lebih baik lagi dan bagi regulator agar dapat menciptakan system dan peraturan baku dalam penentuan pengungkapan ISR untuk perusahaan berbasis syariah.

2. Peneliti berikutnya bisa menggunakan variabel lain yang dapat mempengaruhi pengungkapan ISR dan kinerja keuangan

3. Melakukan kebaharuan yang disesuaikan terhadap indeks ISR yang digunakan untuk meneliti pengungkapan ISR pada penelitian selanjutnya. Karena pada setiap organisasi (perbankan/ perusahaan) memiliki kebutuhan yang berbeda 


\section{DAFTAR PUSTAKA}

Adisaputra,T. F. Khadir, Abdul R. Minizu M. 2016.“Pengaruh Islamic Social Reporting Terhadap Kinerja Keuangan, Zakat Sebagai Intervening pada Bank Umum Syariah di Indonesia".

Arsyi, Abi Rafdi. 2016. “Pengaruh Pengungkapan Islamic Social Reporting Terhadap Return On Assets ( Studi Kasus Bank Umum Syariah Di Indonesia)". Prosiding Manajemen Universitas Islam Bandung , Hal. 24606545.

Amirul Khoirudin. 2013. Corporate Governance Dan Pengungkapan Islamic Social Reporting pada Perbankan Syariah di Indonesia. Accounting Analysis Journal, Volume 2 Nomor 2. Semarang: Universitas Negeri Semarang

Cahyani, Ribut Sri Rahayu dan Ari Dewi. (2014). “Faktor-faktor yang Mempengaruhi Pengungkapan Corporate Social Reporting (CSR) pada Perbankan Syariah". Jurnal Riset Akuntansi dan Keuangan , Vol. 5 No. 2, 74-87. Chariri, Charles. 2012. "Analisis Pengaruh Islamic Corporate Governance Terhadap Pengungkapan Corporate Social Responsibilty (Studi Kasus pada Bank Syariah di Asia)". Diponegoro Journal of Accounting , Hal. 1-15.

Etty, Murwaningsari. 2009. Hubungan Corporate Governance, Corporate Social Responsibilites dan Corporate Financial Performance Dalam satu Continuum. Jurnal Akuntansi \&Keuangan. Vol 11.No.1. 30-41.

Firman, Eka Widiastuti dan M. Asmeldi. 2016. "Faktor Non Financial dan Islamic Social Reporting Disclosure Perbankan Syariah Indonesia". Jurnal Akuntansi dan Keuangan Syariah , 183-214.

Ghozali, Imam. 2018. Aplikasi Analisis Multivariate dengan Program IBM SPSS 25. Semarang: Badan Penerbit Undip.

Haniffa, R. and Hudaib, M.A. 2002. A theoretical framework for the development of The Islamic perspective of accounting, Accounting, Commerce \&Finance: The Islamic Perspective Journal, Vol. 6 No. 1\&2, Malaysia

Harahap, Nurlalila. Hendra H., Saparuddin S., Nova M. 2017. “Pengaruh Islamic Social Reporting (ISR), Umur Perusahaan, dan Kepemilikan Saham Publik Terhadap Profitabilitas (ROA) pada Perusahaan yang Terdaftar di Jakarta Islamic Index (JII) Tahun 2010-2014". KITABAH , 70-91.

Haribowo, Ismawati. 2015. "Analisis Pengaruh Islamic Corporate Governance Terhadap Corporate Social Responsibility". Jurnal Bisnis dan Manajemen , Vol. 5, Hal. 147-172.

Lanis, Sayd Farook dan Roman. 2005. "Banking on Islam? Determinants of Corporate Social Responsibility Disclosure". International Conference on Islamic Economics and Finance , Hal. 355-388.

Lindblom, C K. 1994. "The Implications of Organizational Legitimacy for Corporate Social Performance and Disclosure". Presented at The Vritical Perspective on Accounting Conference .

Othman, Rohana dan Azlan Md Thani. (2010). "Islamic Social Reporting of Listed Companies In Malaysia". International Business \& Economics Research Journal , Vol. 9 No.4, 135-144.

Peraturan Bank Indonesia No. 11/3/PBI/2009 Tentang Perbankan Syariah.

Peraturan Bank Indonesia No. 11/33/PBI/2009 Tentang Pelaksanaan Good Corporate Governace Bagi Bank Umum Syariah dan Usaha Unit Syariah.

Dampak Islamic Corporate Governance , Islamic Social Reporting Pada Kinerja Keuangan Bank Syariah di Indonesia 
Peraturan Bank Indonesia No. 8/4/PBI/2006 Tentang Pelaksanaan Good Corporate Governance bagi Bank Umum.

Peraturan Bank Indonesia No.6/24/PBI/2004. (2004). Bank Umum yang Melaksanakan Kegiatan Usaha Berdaarkan Prinsip Syariah.

Purwanti, Ari. 2016. “Dewan Pengawas Syariah dan Pengungkapan Aspek Lingkungan, Produk dan Jasa pada Bank Syariah". Jurnal Akuntansi dan Keuangan Islam , 4, No. 2.

Ramadhani, Febri. 2016. "Pengaruh Ukuran Perusahaan, Profitabilitas, Laverage dan Ukuran Dewan Pengawas Syariah Terhadap Pengungkapan Islamic Social Reporting". JOM Fekon, Vol. 3, 2487-2500.

Taufiq, Marlina Widianto, Rafiqoh. 2015. “Pengaruh Islamic Governance Score, Leverage dan Profitabilitas Terhadap Islamic Social Reporting Index pada Bank Umum Syariah di Indonesia. Jurnal Manajemen dan Bisnis Sriwijaya, Vol. 13, 177-198.

Undang-Undang No. 40 Tahun 2007 Pasal 74 Tentang Perseroan Terbatas Terkait dengan Corporate Social Responsibility. 


\section{LAMPIRAN}

\section{Tabel 1}

Uji Normalitas, Multikolinearitas dan Heterokedastisitas

\begin{tabular}{llll}
\hline & Kolmogorov-SmirnovZ & VIF & Sig \\
\hline $\begin{array}{l}\text { Ukuran dewan pengawas } \\
\text { syariah }\end{array}$ & 1.148 & 3.302 & 0.679 \\
$\begin{array}{l}\text { Keahlian dewan } \\
\text { pengawas syariah }\end{array}$ & 0.753 & 2.221 & 0.518 \\
\hline
\end{tabular}

Sumber : Data diolah 2019

\section{Tabel 2}

Hasil SPSS Regresi Linier Berganda dan Nilai t-Hitung

\begin{tabular}{|c|c|c|c|c|c|}
\hline \multirow{2}{*}{$\begin{array}{c}\text { Model } \\
\text { B }\end{array}$} & \multicolumn{2}{|c|}{ Unstandardized Coefficients } & \multirow[t]{2}{*}{$\begin{array}{l}\text { Standardized } \\
\text { Coefficients }\end{array}$} & \multirow{2}{*}{$t$} & \multirow{2}{*}{ Sig. } \\
\hline & Std. Error & Beta & & & \\
\hline (Constant) & .091 & .239 & & .381 & .001 \\
\hline UDPS & .031 & .001 & .000 & .002 & .004 \\
\hline KDPS & .014 & .011 & .239 & 1.279 & .074 \\
\hline
\end{tabular}

a. Dependent Variable: Perusahaan Islamic Social Report (ISR)

Hasil SPSS Regresi sederhana dan Nilai t-Hitung

\begin{tabular}{|c|c|c|c|c|c|c|}
\hline & \multirow{2}{*}{$\begin{array}{c}\text { Model } \\
\text { B }\end{array}$} & \multicolumn{2}{|c|}{ Unstandardized Coefficients } & \multirow[t]{2}{*}{$\begin{array}{c}\text { Standardized } \\
\text { Coefficients }\end{array}$} & \multirow{2}{*}{$\mathrm{t}$} & \multirow{2}{*}{ Sig. } \\
\hline & & Std. Error & Beta & & & \\
\hline \multirow{2}{*}{1} & (Constant) & .642 & .054 & & 11.779 & .248 \\
\hline & ISR & .046 & .041 & .351 & 1.126 & .039 \\
\hline
\end{tabular}

a. Dependent Variable: Kinerja Keuangan 